\title{
KILOMETER 500, DIE BEËINDIGING VAN DIE SUIDWES-AFRIKA-KAMPANJE 70 JAAR GELEDE
}

\author{
Mnr. J.J. Bruwer*
}

Examining the final Military actions of July 1915, which led to the historic events of the 9th of July $\mathbf{1 9 1 5}$ at Kilometer $\mathbf{5 0 0}$, the turning point of these events may be easily identified. It was namely at the point in time when the German Forces retreated to Khorab, and the Otavi - Otavi Mountains - Elephant Mountain area came into the possession of the Union Forces. This article deals with the chain of events leading to and surrounding the conclusion of the South West Africa Campaign 70 years ago.

Weggesteek langs die spoorlyn nét noordoos van Otavi, staan ' $n$ beskeie monumentjie wat in 1973 tot 'n nasionale gedenkwaardigheid verklaar is. Op die bronsplaat wat op die monu- mentjie voorkom, lees ' $n$ mens die volgende: "This marks the place where hostilities terminated in South West Africa, 9th July, 1915."
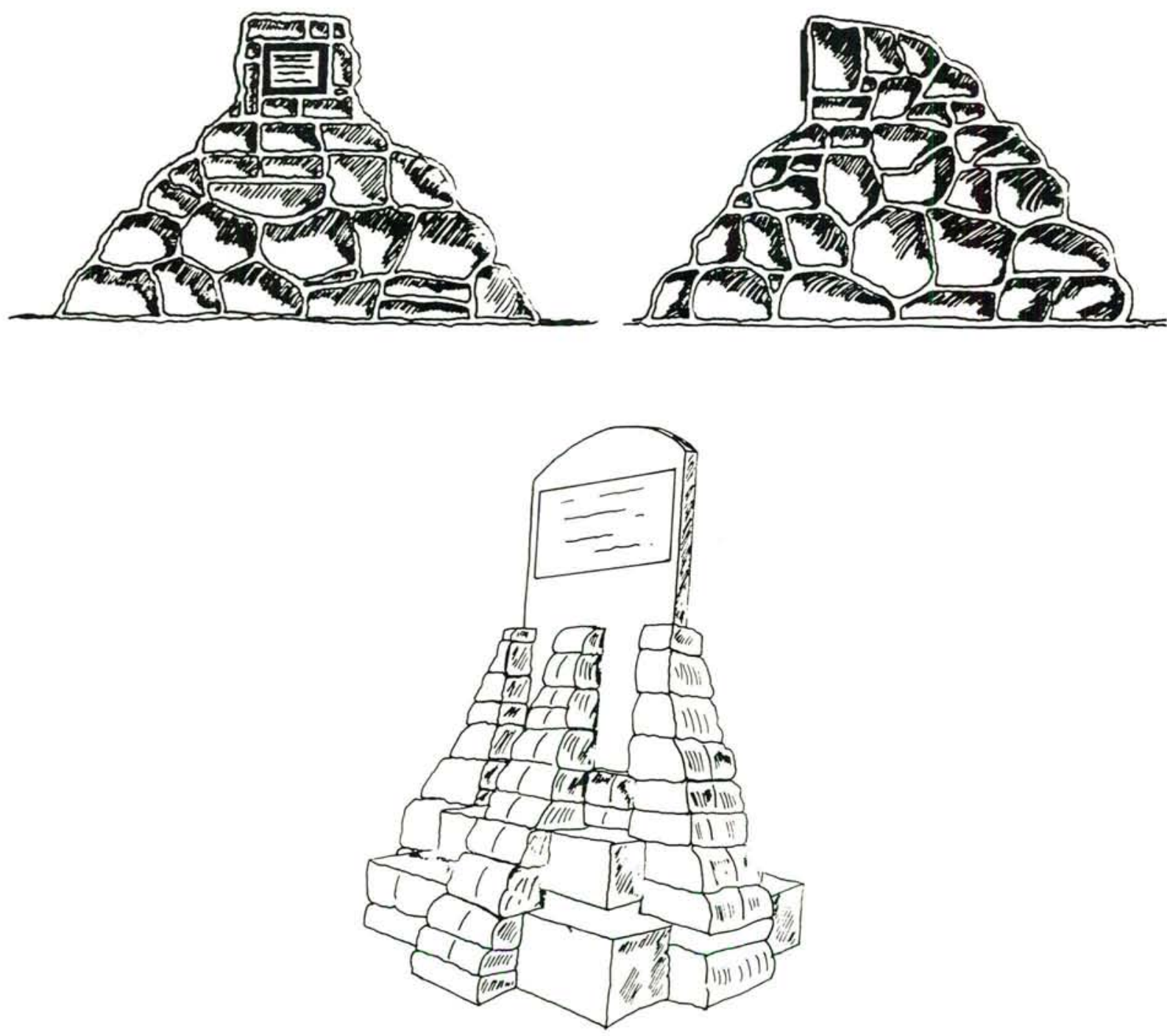
Die vyandelikhede waarna verwys word was dié wat in Suidwes-Afrika tydens die Eerste Wêreldoorlog plaasgevind het en waartydens die gewapende magte van die Unie van Suid-Afrika en dié van die Duitse Protektoraat van SuidwesAfrika, op die slagveld kragte gemeet het. Hierdie oorlog, wat altoos as die Suidwes-Afrikakampanje bekend staan het minder as 'n jaar geduur. Teen Junie 1915, ietwat meer as ' $n$ halfjaar na die begin van vyandelikhede, was die setel van die Duitse Protektoraatregering naamlik Windhoek, asook die strategies geleë dorpie Karibib, verder na die noordweste, reeds in Suid-Afrikaanse hande.
Op 18 Junie 1915 het die Uniemagte onder leiding van generaal Louis Botha, met hulle aanmars verder noordwaarts teen die terugvallende Duitse magte begin. ${ }^{1}$ Dit was gou duidelik dat die Krygsbevelhebber van laasgenoemde, Oberstleutnant Franke, glad nie wou hê dat sy manne in 'n grootskaalse geveg met sy opponent betrokke raak nie. Daar was trouens gerugte dat hy beplan het om sy magte by dié van die legendariese generaal Von Lettow-Vorbeck, in Oos-Afrika te laat aansluit.

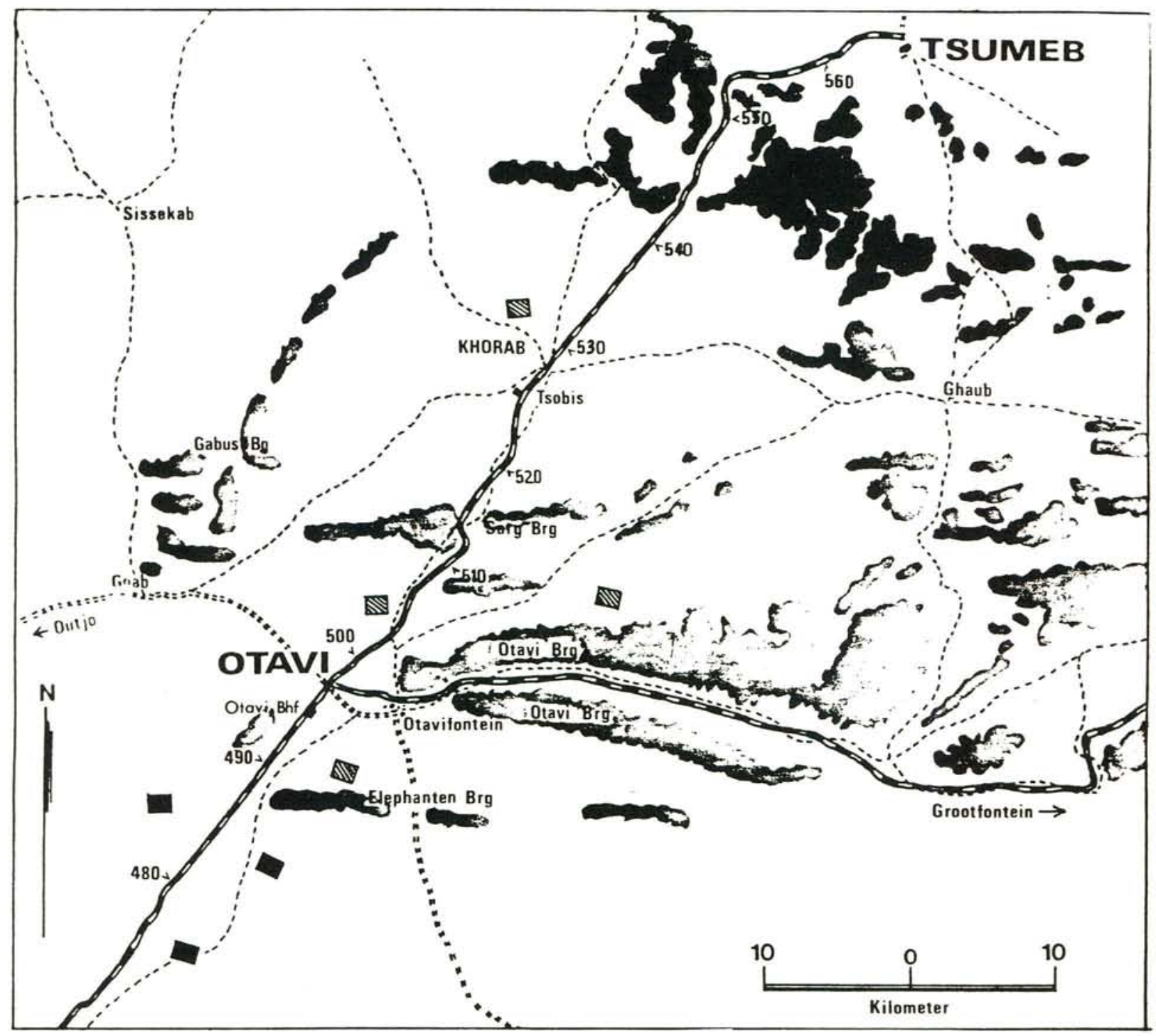

30 Junie 1915

TROEPE

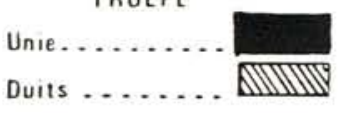

Hoofroetes $\quad z=: z=z:=$ :

Sekondere roetes ........ 
Op 1 Julie 1915 het die laaste noemenswaardige gevegte in die kampanje in die omgewing van Otavi-Otavifontein en by Elephantenberg, suid hiervandaan plaasgevind. Dit het skielik gelyk asof die Duitse magte moontlik van voornemens was om teen die aanmars van die Uniemagte te begin vasskop. Generaal Louis Botha het genoeg rede gehad om hieroor bekommerd te wees. Die hoofelement van die Duitse magte was op daardie stadium in besit van die goeie waterpunte in die Otavi-Otavifonteinomgewing. Water vir die gevegselemente van die Uniemagte is in teenstelling hiermee, vanaf sover as Okaputa, 65 kilometers suidwes van Otavi aangery. Om sake vir generaal Botha se manne te vererger was die flankgebiede van die Duitse verdedigers van die Elephantenberg, volgens inligting met myne besaai. $^{2}$

Dit is in die lig hiervan dat dit eintlik vir generaal Botha 'n verrassing was toe tyding gedurende die oggend van 1 Julie 1915 ontvang is, dat die Duitsers na die omgewing van Khorab, noordoos van Otavi, aan die terugval was. Hierdie verwikkeling het gevolg op ' $n$ verrassingsaanval teen die Duitse Elephantenbergstellings deur 5 Berede Brigade van brigadier Manie Botha in die vroeë donker oggendure van 1 Julie $1915 .^{3}$ Die vlugtigheid van dié operasie het die Duitsers onkant gevang en die byna waaghalsige eksploitasie-aksie wat op die aanvanklike sukses van die aanval gevolg het, was vir die skielike Duitse ontruiming van die sterktepunte by Otavi en Otavifontein verantwoordelik.

In taktiese terme was die Duitse ontruiming van die Otavi-Otavifonteinomgewing en die Elephantenbergposisies, 'n stap agteruit. Hierdie aksie en die opsegging van die strategies-geleë Otaviberge, het in werklikheid beteken dat die manne van Oberstleutnant Franke gou goeie vasskopplek verloor het. Word na 'n kaart van die gebied tussen Otavi en Tsumeb gekyk, is dit opvallend dat dié gebied homself tot ideale verdediging teen aanvallers van buite mag leen. Die uitleg van die berg- en heuwelagtige terrein wat hierdie betrokke gebied omsoom, is opvallend. Die gevegselemente van generaal Botha se magte wat teen die laatmiddag van 1 Julie 1915 in besit van Otavi en Otavifontein sowel as die Otaviberge oos hiervan was, het op die drumpel van ' $n$ ooglopende verdedigingswaardige gebied gestaan.

Die hoofelement van die Duitse magte was op 2 Julie 1915 by Khorab en tussen Kilometers 510 en 520, met kleiner afdelings by Ghaub en in die heuwels by Goab en Gabus ontplooi. Brigadier Manie Botha se brigade was in die Otavi-Otavifonteinomgewing, en 6 Berede Brigade onder die bevel van brigadier Lukin ten weste van Otavi gekonsentreer. Kritiek vir die Duitsers, was dat 1 Berede Brigade van brigadier Coen Brits, en 2 en elemente van 3 Berede Brigades onder bevel van brigadier Myburgh, onderskeidelik in omflankingsaksies via Okaukuejo na Namutoni en via Grootfontein na Tsumeb aan die opruk was. $^{4}$

Lugverkenning op 3 Julie 1915 het daarop gedui dat die Duitsers steeds in hulle stellings van die vorige dag ontplooi was, en dat hulle skynbaar geen nuwe stellingverskuiwings beplan het nie. ${ }^{5}$ Volgens generaal Botha se Stafhoof, brigadier Collyer, het dít vir die Uniemagte swarigheid voorspel. Die Khorabgebied was op die inligtingskaart as ' $n$ besonder ideale verdedigingsposisie aangedui. ${ }^{6}$ Collyer het uiteraard geen insig in die werklike situasie in Duitse geledere op 3 Julie 1915 gehad nie. Indien wel, sou hy meer optimisties oor die krygsvooruitsigte van sy eie magte gevoel het.

Die feit van die saak is dat Oberstleutnant Franke oor genoegsame rede beskik het om wanhopig oor die toekoms van sy eie magte te voel. Hy het vir goewerneur Seitz wat by Grootfontein was, reeds gedurende die laat ure van 2 Julie 1915 by wyse van 'n syfertelegram versoek om na Khorab vir samesprekings te kom. Tydens die ontmoeting wat op 3 Julie 1915 tussen Franke en Seitz gevolg het, was ook Oberstleutnant Bethe, Bevelvoerder van die Polisie, en Leutnant en Major Bauszus teenwoordig. ${ }^{7}$ Alhoewel Seitz met Franke verskil het oor die klaarblyklike hopeloosheid van die Duitse magte se posisie, was dit voor-die-handliggend dat nie hy nie, maar Franke die krygsbevelhebber was, en daarom die verantwoordelikheid vir verder krygsoptrede moes dra.

Volgens Franke sou dit futiel wees om die Khorabgebied in ' $n$ vesting te probeer omskep en verdere weerstand te bied. Logistieke faktore soos karige mediese geriewe vir die versorging van gewondes, swak vooruitsigte op onbepaalde ammunisievoorsiening, en ontoereikende materiaal om goeie verdedigingstellings mee te bou, het beteken dat ' $n$ beleg van die Duitse magte by Khorab op blote selfmoord sou neerkom. Dan was daar ook die probleem dat weiding vir perde en trekdiere by Khorab skaars was. Die omflankingsaksie van brigadier My- 
burgh se magte was altoos ook die eerste stap in die uiteindelike beleëring van die Duitse hoofmag by Khorab. Om onder dié omstandighede nog te probeer om in die rigting van Angola of selfs die Kavango terug te val, was prakties onuitvoerbaar. Die Portugese van Angola was die Duitsers vyandiggesind en buitendien was brigadier Coen Brits vinnig op pad om Namutoni, die toegangshek na Angola, in besit te neem. Die swak toestand van die perde en trekdiere by Khorab, en die vermoeiende eise wat selfs ' $n$ tog na die Kavango aan Franke se manne sou stel, het die Duitsers met geen alternatief gelaat nie as om oor te gee. ${ }^{8}$

'n Afgevaardigde van dr Seitz het teen sononder op 3 Julie 1915 by Otavi aangekom en 'n brief van Seitz aan generaal Botha oorhandig. In hierdie brief is voorgestel dat vyandelikhede beëindig en die Duitse magte met die behoud van hulle wapentuig en oorlogsmateriaal, vir die res van die ooglog in krygsgevangeneskap gehou word. ${ }^{9}$ Hierdie voorstel was vir generaal Botha onaanvaarbaar. Hy het op 'n onvoorwaardelike Duitse oorgawe aangedring.

Die afgevaardigde van dr Seitz het gedurende die middag van 4 Julie 1915 weer by generaal Botha se hoofkwartier opgedaag en laasgenoemde tóé versoek om voorwaardes te formuleer wat as basis vir die beëindiging van vyandelikhede kon dien. Generaal Botha het meer positief op hierdie voorstel geantwoord en op 5 Julie 1915 het goewerneur Seitz daarom gevra dat hy generaal Botha persoonlik vir verdere gesprekvoering ontmoet. Sodanige ontmoeting is vir 6 Julie 1915 by Kilometer 500 gereël. ' $n$ Wapenstilstand tussen die strydende magte wat tussen Otavi en Khorab ontplooi was, is inmiddels deur generaal Botha afgekondig. ${ }^{10}$

Voordat hierdie wapenstilstand egter ter sprake gekom het, is ' $n$ afdeling van die Duitse hoofmag onder die bevel van Hauptmann Von Kleist wat by Ghaub ingegrawe was, deur flankelemente van brigadier Myburgh se brigade aangeval en na posisies nader aan Khorab, en oos van die spoorlyn teruggedryf. Die Duitse gevegselemente van Hauptmann Graf Saurma wat by Goab, Gabus en noord hiervandaan by Sissekab ontplooi was, is op 4 Julie 1915 na stellings nader aan Khorab terugbeveel. ${ }^{11}$ Die resultaat van hierdie stellingverskuiwings, was dat Oberstleutnant Franke se magte teen die aand van 5 Julie 1915 in geheel by Khorab in 'n rondom verdedigingsektor ontplooi was. Die Duitse garnisoene van Tsumeb en Namutoni, was nie deel hiervan nie. 'n Duitse observasieelement by Kilometer 514 , het Franke van vyandelike troepebewegings op hoogte gehou. ${ }^{12}$

Met die koms van 6 Julie 1915 het 'n betekenisvolle uur in die verhaal van die kampanje in Suidwes-Afrika aangebreek. Vóór hierdie dag om was, het die Duitse garnisoene van Tsumeb en Namutoni onderskeidelik voor brigadiers Myburgh en Brits se brigades geswig, en is voorlopige vredesvoorwaardes deur goewerneur Seitz en generaal Botha by Kilometer 500 geformuleer. ${ }^{13}$ Hierdie voorwaardes moes vervolgens en voor enigiets anders, deur die Unieregering goedgekeur word. 'n Algehele wapenstilstand tussen die Unie- en Duitse magte het om $12 \mathrm{~h} 00$ op 6 Julie 1915 in werking getree. Gedurende die vroeë ure van 8 Julie 1915 het generaal Botha tyding by sy hoofkwartier in Otavifontein ontvang dat die vredesvoorwaardes van 6 Julie 1915 met enkele wysigings deur die Unieregering aanvaar is. ${ }^{14}$ Hierdie gewysigde voorwaardes is hierna na Khorab vir aanvaarding gestuur.

Om presies 10 h00 op 9 Julie 1915 het goewerneur Seitz, Oberstleutnanten Franke en Bethe, en enkele junior Duitse offisiere per trein by Kilometer 500 met die oog op die ondertekening van die kapitulasie-ooreenkoms aangekom. Generaal Botha en sy geselskap, bestaande uit kolonel Collyer (Stafhoof), luitenant-kolonel De Waal (Hoofprovoos), majoor Bok (Militêre Sekretaris, majoor Esselen (Stafoffisier) en majoor Leisk, was reeds by Kilometer 500 aanwesig, en het die Duitse afvaardiging ingewag en verwelkom. ${ }^{15}$

' $n$ Konferensie het hierop in die onmiddellike omgewing van 'n Omupararaboom (Peltophorum africanum), ' $n$ byna 30 meter wes van die spoorlyn plaasgevind. "... the conference" volgens Collyer, "soon became occupied in arriving at the finale form of the terms of surrender... when the document had assumed a mutually acceptable tone it was signed by General Botha, Dr. Seitz and Colonel Franke and the conference broke up." ${ }^{16}$ Hierdie ondertekeningseremonie het in 'n kamptent geskied wat spesiaal vir die geleentheid naby die Omupararaboom opgeslaan was. Die tentklappe van die tent was ver opgeklap om genoegsame lig binne die tent te verskaf en vrye toegang na en beweging in die tent moontlik te maak.

Enkele foto's oor die geskiedkundige gebeurtenis by Kilometer 500 op 9 Julie 1915, toon aan 


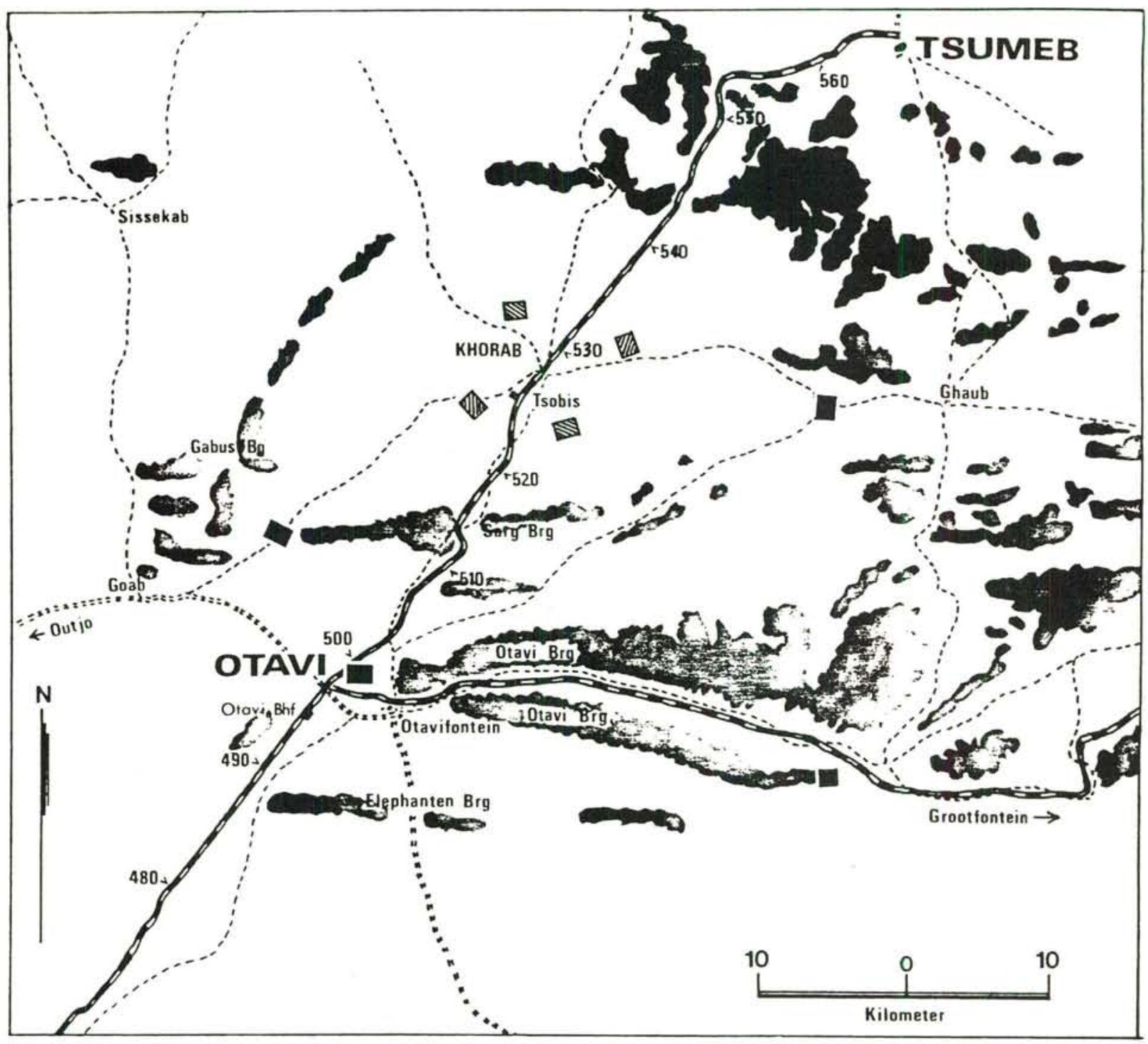

5 Julie 1915

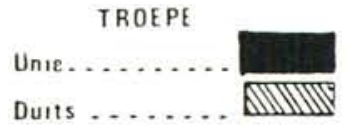

dat generaal Botha, goewerneur Seitz en onder andere Oberstleutnant Franke, op 'n stadium op stoele by 'n tafel nét langs die tent gesit en op 'n skynbare informele wyse oor die kapitulasievoorwaardes gekonfereer het. Ván die junior offisiere wat Seitz na Kilometer 500 vergesel het, was óók op 'n stadium in 'n staande posisie by hierdie gesprekvoering betrokke. Dit bly 'n raaisel of die foto's hier ter sprake, direk vóór of ná die ondertekening van die kapitulasie-ooreenkoms geneem is. Hoorsê-getuienis wil dat hierdie ooreenkoms in die skaduwee van die Omupararaboom by Kilometer 500 onderteken is. Dít konstateer ' $n$ verdraaiing van die geskiedenis. 


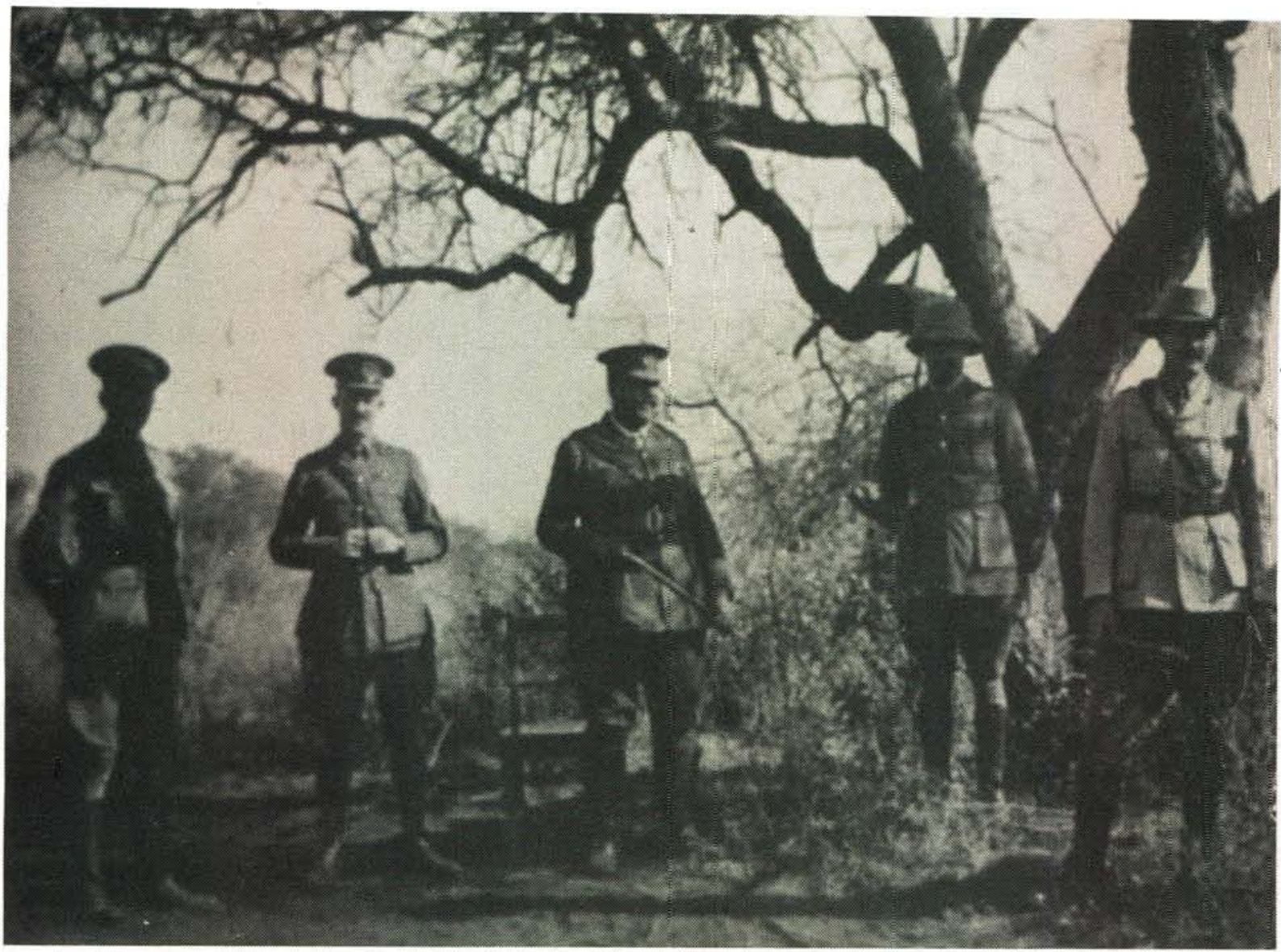

Genl. Botha en Staf wag op koms van Duitse vredesafvaardiging, 9 Julie 1915. Van I na r: It-kol De Waal, kol Collyer, genl Botha, maj Bok en maj Esselen (Foto: Staatsargief, Windhoek)

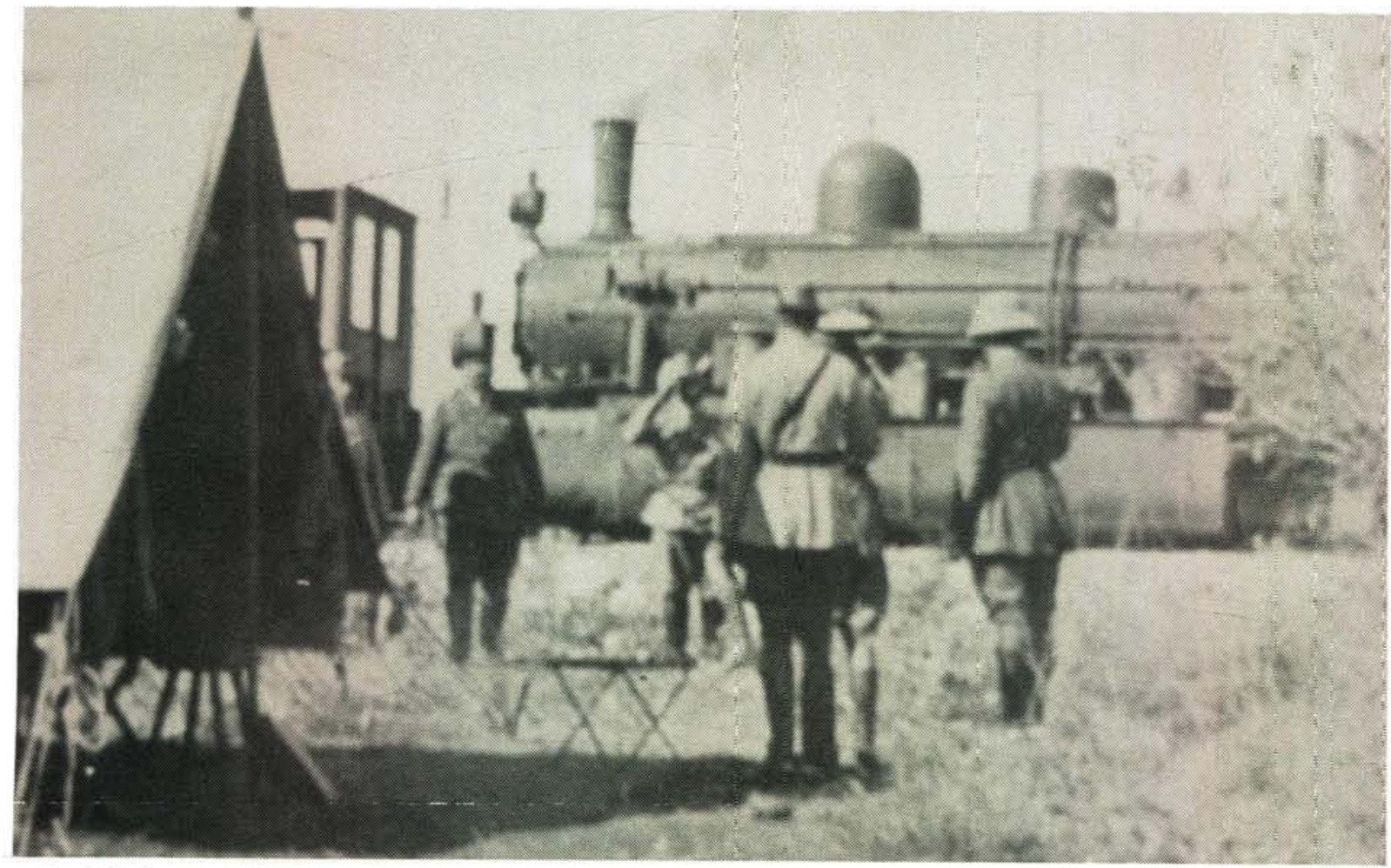

Genl Botha en sy Staf verwelkom goewerneur Seitz en Obersleutnant Franke by Kilometer 500 (Foto: Staatsargief, Windhoek) 


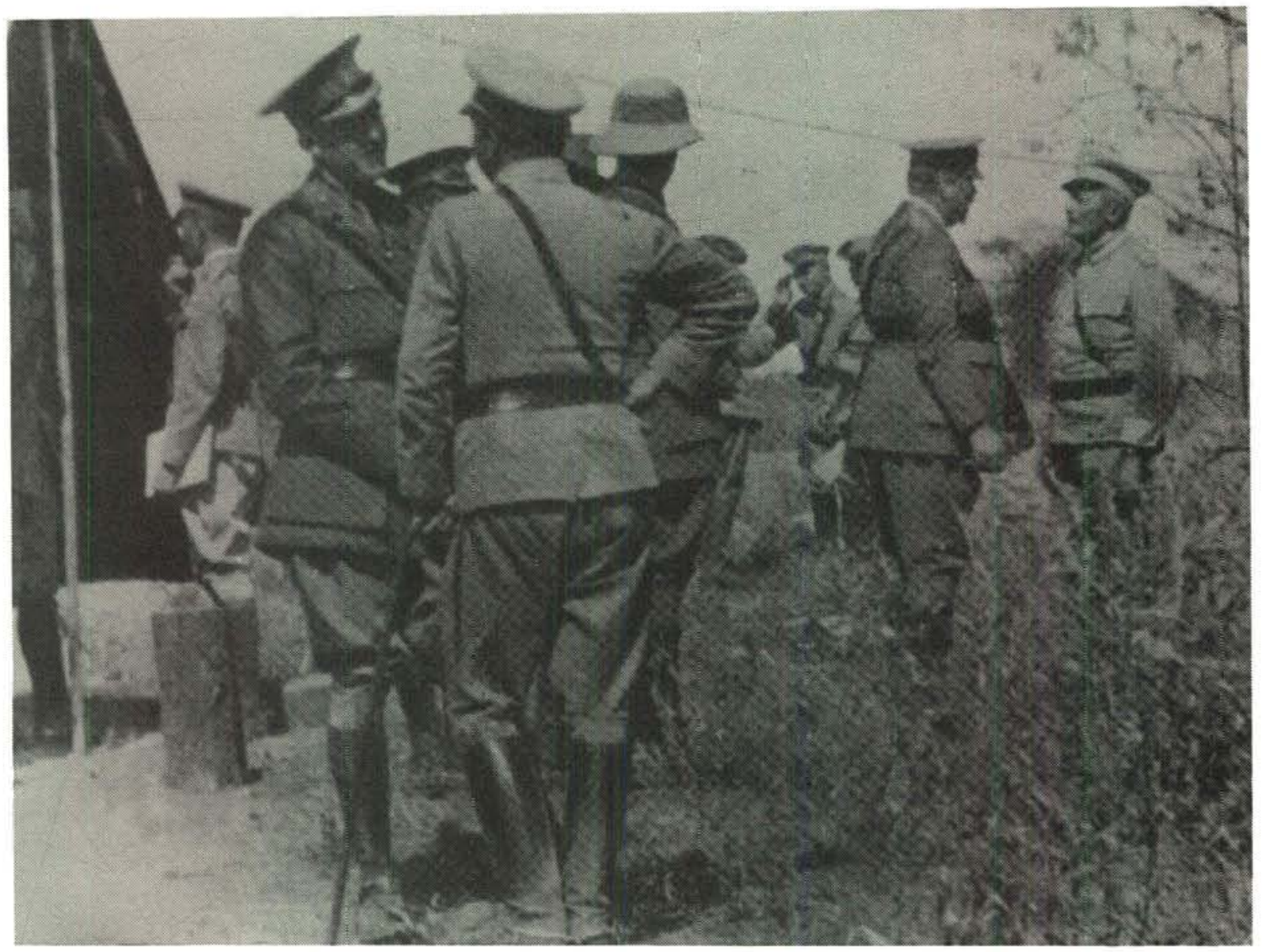

Die Unie- en Duitse afvaardigings voer informele gesprekke (Foto: Staatsarglef, Windhoek)

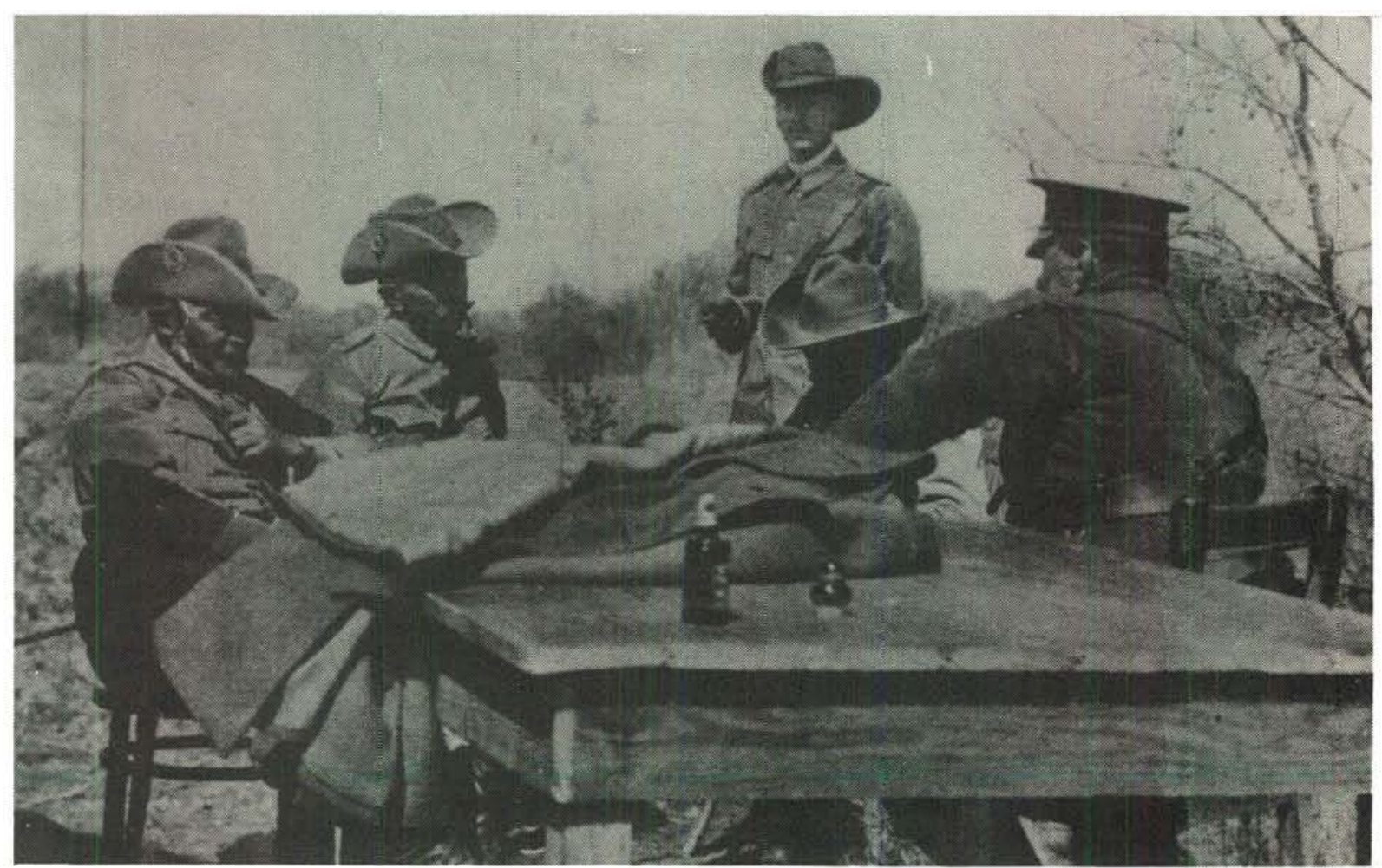

Goewerneur Seltz en Obersleutnant Franke konfereer met genl Botha oor dle vredesvoorwaardes (Foto: Staatsargief, Windhoek) 
Die kapitulasie-ooreenkoms is andersyds en uit die aard van bogenoemde skrywe, nie by Khorab self onderteken nie. Dit het wel na 1915 as die Verdrag van Khorab bekend gestaan en dit blyk die rede te wees vir die misleidende aanduiding van die presiese plek van die kaputilasie wat steeds bestaan. Die Duitse magte wat op 9 Julie 1915 gekapituleer het, was wel by Khorab saamgetrek. Met inbegrip hiervan was dit nie Khorab nie, maar Kilometer 500 wat prominent in die gebeure noord van Otavi op 9 Julie 1915 gefigureer het.

Die taak om na die implementering van die kapitulasie-voorwaardes om te sien, is aan brigadier Lukin opgedra. Een hiérvan was dat al die onder-offisiere en manskappe van die aktiewe Duitse mag en Polisie, vir die duur van die oorlog in Europa en op die ander gevegsfronte, krygsgevange gehou sou word. Hulle is na 'n kamp wat vir die doel, by Aus in die suide van Suidwes-Afrika opgerig is, gestuur. Dié offisiere wat nie bereid was om ooreenkomstig hulle erewoord op ' $n$ spesifieke plek van hulle eie keuse ná loslating te gaan woon nie, is in 'n krygsgevangenekamp by Okanjande naby Otjiwarongo en daarna op Swakopmund aangehou. Die reserviste wat in die Duitse magte geveg het, is toegelaat om na hulle tuistes terug te keer.

Daar is weinig bekend oor die fisiese verloop van die Duitse oorgawe wat op die ondertekening van die kapitulasie-ooreenkoms gevolg het. "The formal surrender" volgens Wilson, "took place at Otavi, where the prisoners began to arrive on July 11 th. Several of them were wearing a cross, not of iron, but of black cloth edged with white cord, this being apparently the nearest approach they could get to the decoration so dear to the Kaiser's heart. ${ }^{.17}$

Op 27 Julie 1915, meer as twee weke na die ondertekening van die vredesverdrag by Kilometer 500, het brigadier Lukin aan die Unieverdedigingsmag-hoofkwartier in Pretoria laat weet dat Khorab ontruim was. Die laaste trein met Duitse krygsgevangenes het om 03h00 op 27 Julie 1915 vanaf Tsumeb vertrek. ${ }^{18}$

Kyk 'n mens na die finale krysgebeure van Julie 1915 wat tot die historiese gebeure van 9 Julie 1915 by Kilometer 500 gelei het, is die keerpunt in hierdie gebeure, maklik indentifiseerbaar. Dít was naamlik toe die Duitse magte na Khorab teruggeval en die Otavi-Otaviberge-Elephantenberggebied in die besit van die Uniemagte gekom het. Hierdie keerpunt het op brigadier Manie Botha se navolging van die twee belangrike oorlogsbeginsels, te wete verrassing en eksploitasie van sukses gevolg. Die omflankingsoperasies van die Khorabgebied kon hierna ongesteurd voortgaan. Die Duitse magte by Khorab was hoegenaamd nie genoegsaam gekonsentreerd om suksesvolle aanvalle teen hierdie omflankingstrategie te loods nie. Die Duitse terugtrekking na Khorab het die Duitse oorgawe wat enkele dae later gevolg het, onvermydelik gemaak. Die Tsumeb-Otavigebied was eintlik 'n goeie strategiese gebied vir defensiewe krygsoptrede maar het helaas as doodsgrond vir die Duitse magte gedien.

Die Duitse oorgawe by Kilomter 500 het in 1919 skielik ter sake gekom toe die destydse Goewerneur-generaal van die Unie, Lord Buxton, Suidwes-Afrika besoek het. Een van die besoekpunte op sy reisprogram was die historiese Kilometer 500, en Lord Buxton het dit wenslik geag om voor te stel dat ' $n$ monument aldaar opgerig word om die gebeure van 9 Julie 1915 te herdenk. ${ }^{19}$ Dié plek waar die kapitulasie-ooreenkoms onderteken is, was op spoorwegeiendom geleë, en die Direkteur van Spoorweë in Suidwes-Afrika was dus daarvoor verantwoordelik om Lord Buxton se voorstel verder te voer.

Die Departement van Werke het 'n ontwerpskets van die voorgestelde monument gedoen en dit in Maart 1920 aan die Administrateur van Suidwes-Afrika vir goedkeuring voorgelê. Die bronsbewoordingsplaat vir die monument is deur die firma Howald en Vollmer van Windhoek gegiet, waarna dit op 10 November 1920 op die monument wat intussen opgerig was, aangebring is. ${ }^{20}$

Vanweë 'n klaarblyklike misverstand tussen die Departement van Spoorweë en dié van Werke, het die vorm en voorkoms van die monument wat by Kilometer 500 opgerig is, hemelsbreed van die oorspronklike ontwerpskets van 1920 verskil. Die monument het nie soos ' $n$ byna natuurlike klipstapel nie, maar eerder soos ' $n$ ietwat verwronge baken gelyk. Die Direkteur van Werke het daarom aan sy saakgelastigde op Omaruru in September 1923 opdrag gegee om stappe te neem om die monument by Kilometer 500 af te breek. ${ }^{21}$ ' $n$ Monument soos oorspronklik ontwerp was, moes in sy plek opgerig word. 'n Probleem het nou ontstaan aangesien die bedrag van $£ 100$ wat hiervoor bewillig was, nie met die resultate van die tenders kon kers vashou wat vir die oprigting van die monument aange- 


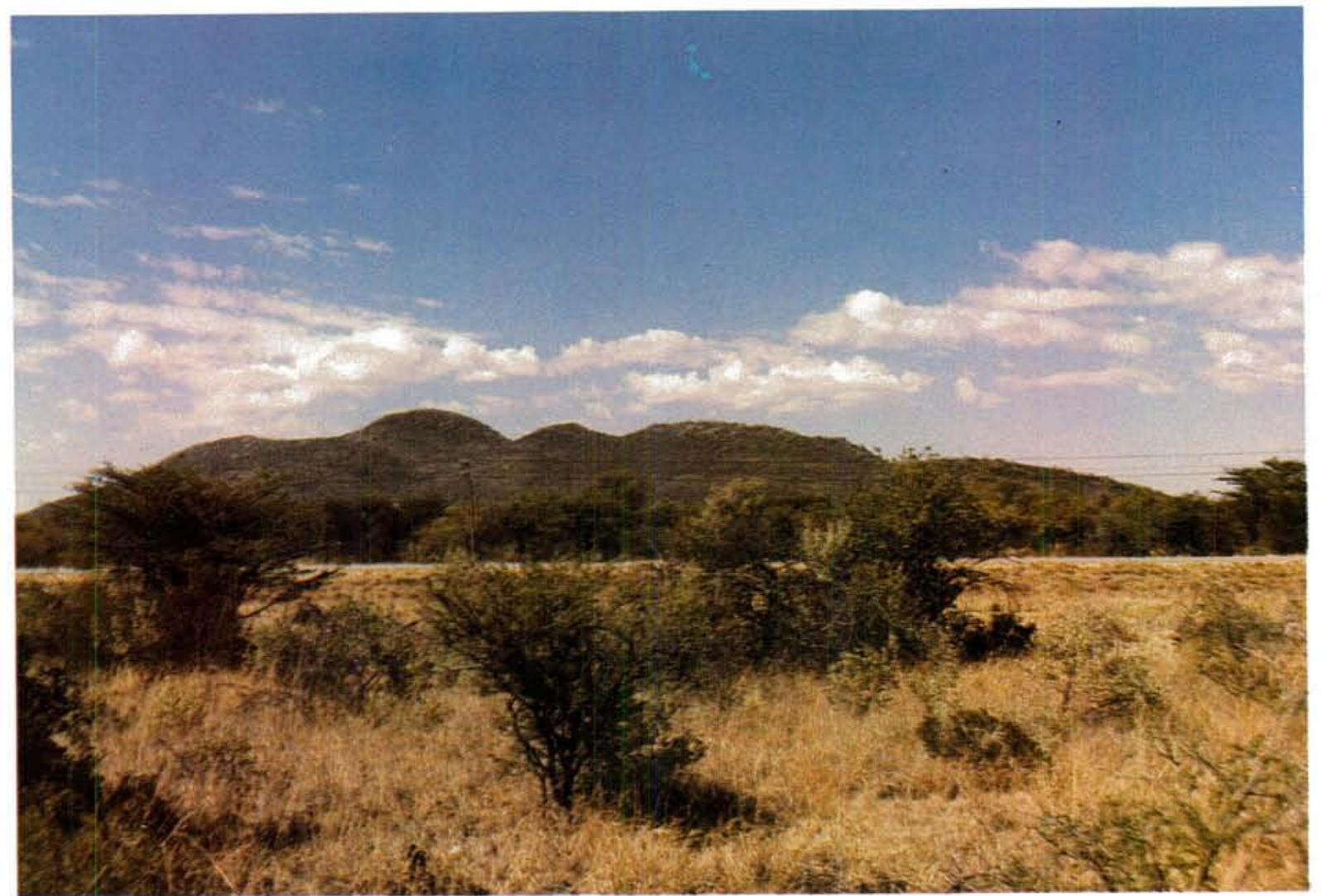

'n Oosfrontblik vanaf die Otavi-Otjiwarongo-pad op die Elephantenberg, 1985

vra is nie. ${ }^{22}$ 'n Gewysigde ontwerpskets is gevolglik in 1925 opgestel. ${ }^{23}$ Dit was gedoen om die beoogde nuwe monument in 'n meer vereenvoudigde vorm en ingelyks teen laer koste, by Kilometer 500 op te rig. Dit is voor-die-handliggend dat niks hiervan gekom het nie. Die monu- ment wat vandag, 65 jaar later by Kilometer 500 te sien is, is dan ook dié een wat in 1920 aldaar opgerig en ' $n$ verklaarde gedenkwaardigheid is.

"Mnr. J.J. Bruwer, MA(RAU) is die SWANNamibië-Streekverteenwoordiger van die Raad vir Nasionale Gedenkwaardighede.

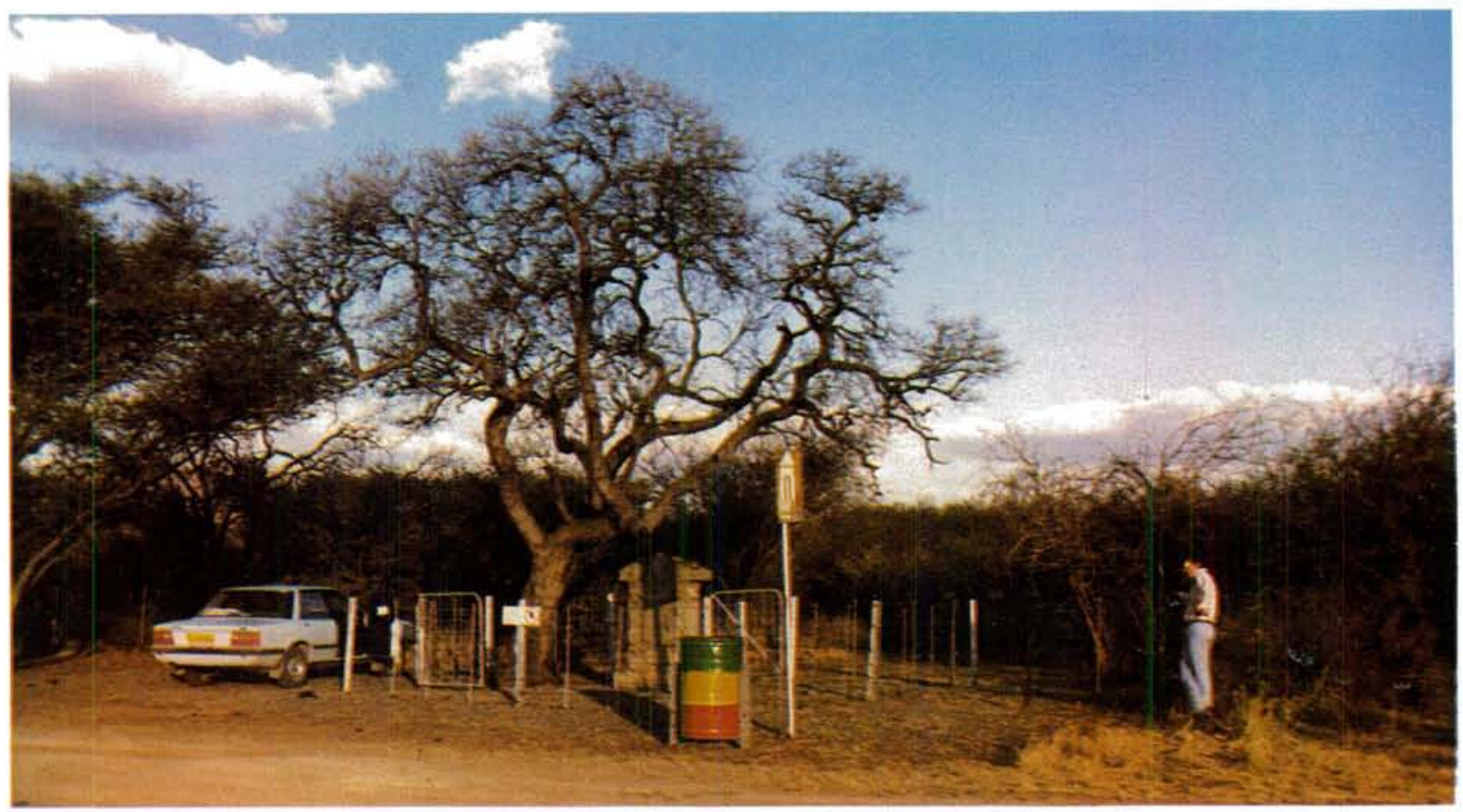




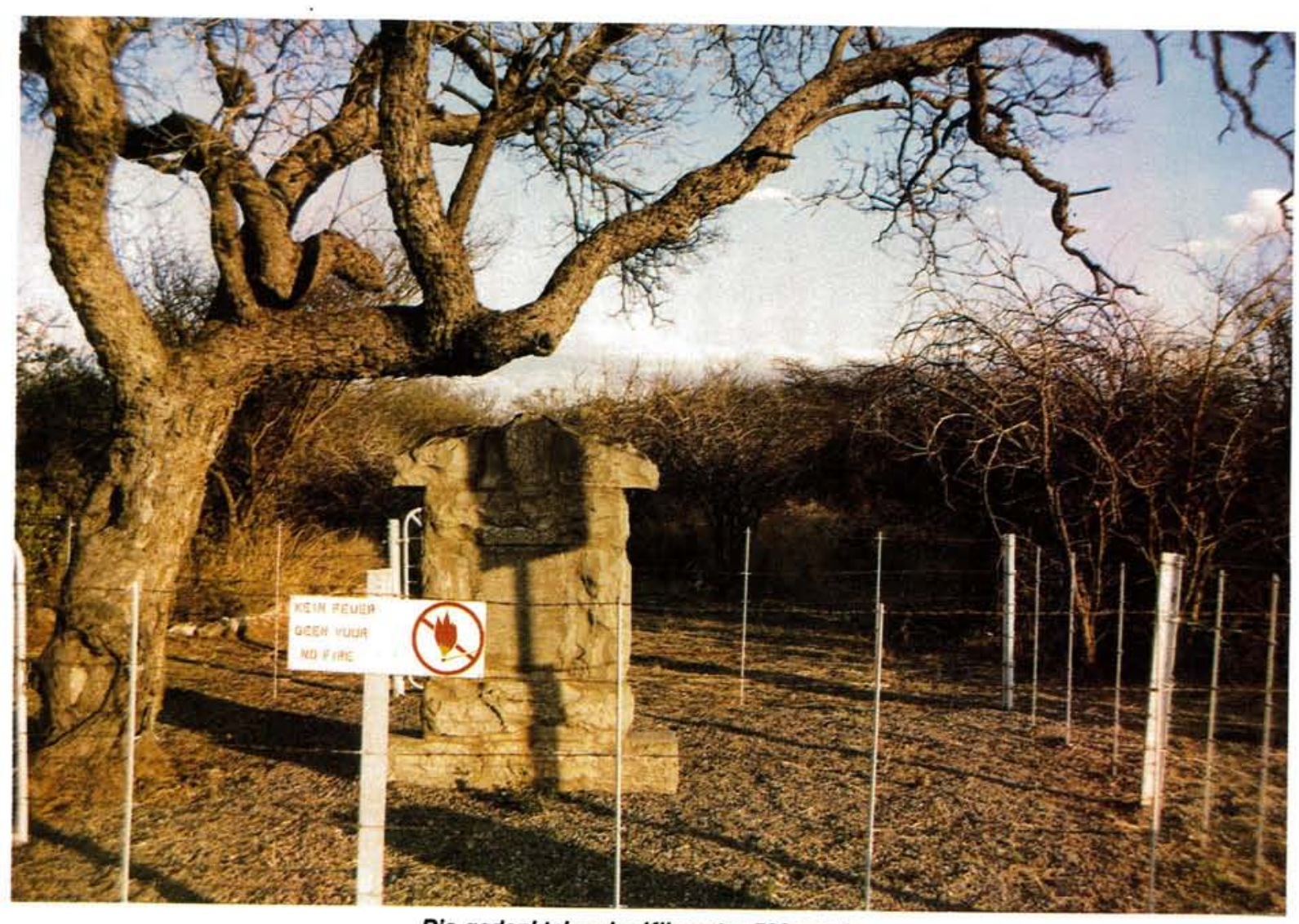

Die gedenkteken by Kilometer 500 vandag

\section{Bibliografie}

1. Official History, Union of South Africa and the Great War, 1914-18 (Pretoria, 1924), p 40.

2. Ibid., p 46 .

3. Ibid., pp 46-47.

4. H. von Oelhafen: Der Feldzug in Südwest, 1914/15 (Berlyn, 1923), p 223; Official History, Union of South Africa.... pp 30-32; J.J. Collyer: The Campaign In German South West Africa, 1914-1915 (Pretoria, 1937). p 151.

5. Collyer: The Campaign .... pp 145 en 147.

6. Ibid., p 145 .

7. Von Oelhafen: Der Feldzug..., p 224

8. Ibid., pp 224-226.

9. Collyer: The Campaign..., p 146.

10. Ibid., p 147.

11. Von Oelhafen: Der Feldzug..., pp 227-228.

12. Ibid., p 227.

13. Collyer: The Campaign..., pp 147-149; Official History, Union of South Africa..., pp 40-41.

14. Collyer: The Campaign..., pp 147-150.

15. Ibid., p 151.; R. Moore: With Botha in the Field (New York, 1915), p 52.

16. Collyer: The Campaign..., p 152.
17. H.W. Wilson (red,): The Great War, The Standard History of the All AllEurope Confict, vol. 4, no. 51, p. 65; vgl. met A.C. Matin: Durban Light Infantry, vol 1, 1854-1934 (Durban, 1959).

18. Suid-Afrikaanse Weermagargief, Secretary for Defence (Medical Defence), lêer no. M/590, Internment Camp Aus: Lukin-Smuts, 27.7.1915.

19. Suidwes-Afrika Argief, Administrator's Department, lêer no. 198/13, Khorab Treaty-Commemoration: Director of Railways - Secretary for the Protectorate, 23.1.1920

20. Suidwes-Afrika Argief, Administrator's Department, lêer no. 198/1. Khorab.... Director of Works - Mnre. Howaldt en Vollmer, 6.6.1921. Suidwes-Afrika Argief, Public Works Department, lêer 223, Stone-Commemoration Peace Treaty Khorab: Director of Railways - Director of Works, 24.1.1921.

21. Suidwes-Afrika Argief, Public Works Department, lêer 223, Stone-Commemoration...: Director of Works - Officer in Charge, P.W.D. Omaruru, 28.9.1923.

22. Ibid., Director of Works-Officer in Charge, P.W.D., Omaruru, 22.11.1923; Suidwes-Afrika Argief, Administrator's Department, lêer no. 198/13, Khorab. ... Director of Works - Secretary for the Protectorate, 16.2.1924.

23. Suidwes-Afrika Argief, Administrator's Department, lêer no. 198/1, Khorab.... Director of Works - Secretary for South West Africa, 10.3.1925. 